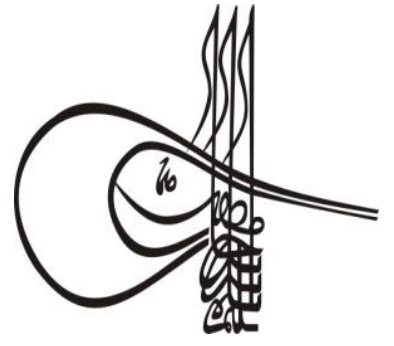

Turkísh Studies CUDES 2019

Volume 14 Issue 5, 2019, p. 93-104

DOI: 10.29228/TurkishStudies.23008

ISSN: 1308-2140

Skopje/MACEDONIA-Ankara/TURKEY

Research Article / Araştırma Makalesi

Article Info/Makale Bilgisi

Received/Geliș: 04.05.2019

$\checkmark$ Accepted/Kabul: 10.08.2019

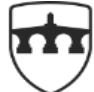

INTERNATIONAL BALKAN UNIVERSITY

EXCELLENCE FOR THE FUTUR IBU.EDU.MK

Report Dates/Rapor Tarihleri: Referee 1 (24.05.2019)-Referee 2 (24.05.2019)

This article was checked by iThenticate.

\title{
POSTMODERN DÜNYANIN MEKÂN ANLAYIŞINDA SANAL MEKÂN
}

\author{
Fatma Senem GÜNGÖR*
}

\begin{abstract}
ÖZ
Sosyal bilimler çalışma kapsamında önemli bir yere sahip olan mekân olgusu, iletişim ve bilgi teknolojilerinin hızla gelişmesi sonucunda anlamsal bir değişime uğramış, sanal ve dijital farkındalıklara yol açmıștır. Bu araștırmada, mekân olgusunun tarihsel düzlemde kazandığı farklı anlamlarından hareketle günümüzde sanal dünyanın mekâna ilişkin yarattığı yeni anlam ve kavrayışlar incelenerek bunun yansımaları postmodern bakış açısıyla ele alınacaktır.

Nitekim mekân olgusu ve bu olgu etrafında oluşturulan anlam örgüsü, dinamik bir alanı işaret etmektedir. 1980'li yıllarda hızlanan postmodernizm araştırmalarının en önemli konu başlıklarından birisi olan mekân, toplumsal pratiklerin şekillendirdiği bir oluşuma girmiştir. $\mathrm{Bu}$ oluşum içinde de toplumsal olarak kimliğin inşasını sağlayan bir kavram olan sanal mekân ortaya çıkmıștır. Bu noktada altı çizilmesi gereken en önemli husus ise gündelik yaşantımızın her alanında karşılaştığımız yeni medya ortamlarının sanal mekânlar yarattığıdır. İnternet aracilığıyla sosyal medya, bloglar, sosyal ağlar gibi sanal mekânlar hem sosyal ilişki biçimlerini hem de anlayışları değiştirmekte, bu bağlamda da yeni medya yoluyla toplumu bir ağ toplumuna dönüştürmekte ve bu ağlar ile önemli toplumsal mekânlar oluşmaktadır. Sonuçta ortaya çıkan toplumsallaşma türü, sanal ortamda oluşmuş mekânlar üzerinden yeni bir toplum yapisı inşa etmektedir.

$\mathrm{Bu}$ sentetik dünya içinde yer alan sanal mekân anlayışı bu araştırmanın merkezinde olup, dijital dünyada oluşan yeni mekânların nasıl belirsizleştiği postmodern düşünce içinde incelenmiştir. Dijital dünyanın kendisi bir sanal mekân sunarken ayrıca kullanıcılar da fiziksel mekânlara ait genel özelliklerin taklitlerini ya da sanal gerçeklik içinde yarattığı temsilleri paylaşır. Postmodern düşünürlerin "hyper
\end{abstract}


mekân” olarak tasvirlediği sanal mekân değişken, sınır tanımaz ve belirgin olmayan bir duruş sergiler. Metinlerarasılık ve çoğulculuk sanal mekân kullanıcıların kullandığı tekniklerden olup, farklı zaman dilimlerini ve mekânları tek bir mekânın içinde verir.

Anahtar Kelimeler: Postmodernizm, Mekân, Sanal Mekân

\title{
THE COMPREHENSION OF VIRTUAL SPACE IN THE POSTMODERN WORLD
}

\begin{abstract}
The concept space that has a significant importance within social sciences has experienced a structural change due to the developed communication and information technologies, and started to gain virtual, digital meanings. In this study, the new meanings and conceptions revealed by the concept virtual today regarding the space shall be analyzed based on the different perceptions of the concept space within the course of history, and their reflections shall be addressed from the postmodern perspective.

Hence, the concept space and the meanings created around that concept points at a dynamic field. As one of the most important issues in the postmodernism discussions that became intense in 1980s, the space has entered into a formation shaped by social practices. Within that formation, the virtual space that is a concept allowing construction of the identity socially has emerged. The important issue that must be highlighted here is the fact that the virtual space environments that penetrated in every field of our everyday life has created new spaces. Virtual space environments such as the Internet, social media, blogs and social networks change both the forms of social relationships and spaces, and in this context, new media turns the society into a network society, and creates important social spaces with these networks. The type of socialization that emerges as a result constructs a new social structure through spaces created in the virtual environment.

Virtual space that is within such a synthetic world is at the center of this study, and how new spaces formed through dijital became vague has been analyzed within the postmodern thought. While dijital world itself offers a virtual space, followers are also provided with the general characteristics of some physical spaces. The space that is depicted by the postmodern thinkers as "hyper space" presents in virtual space a variable and ambiguous stance that knows no boundaries. Intertextuality and pluralism are among the techniques that users use for their followers on virtual space, and it gives different periods of time and spaces within a single space. This article will concern itself with contemporary attitudes towards space.
\end{abstract}




\section{STRUCTURED ABSTRACT}

The nucleus of postmodern philosophy has been highly debated in its history and has been accustomed in a large variation of contexts and situations and remains controversial. Whether it is a rejection of tradition or to renew it, an independance from modernist factual consciousness, a complementary role of late capitalism, or an indefinable Zeitgeist, a key to reconciliation of the postmodern temper is the distinction between truth and illusion. One of the central reasonings of postmodernism is the breakdown of the conventional subject-object relations.

In the twentieth century, the postmodern epoch, the societies start to experience the age of the hyperreal. Here there is not a seperation between reality and the representation; the representation determines the "real". Simulations have become formed on other simulations, and it is unfeasible to mark the origin of the simulacra. This has become the descent path of comprehension of the today's world and is substantiated in the level of ontologyin the virtual space.

This article explores the historical presentation of the understanding/production of space and chart the movement between space and postmodernism. By doing so, it will be shown that how space has changed from an absolute to an abstract one by making a contribution to understanding and interpreting postmodern space that bears the mark of the virtual. Focusing on the postmodernist, hyper textual and material characteristics of virtual spaces will be illustrated by highlighting how postmodern space is characterized not by a new conception of space, but by a new conception of the way space is filled.

The postmodern understanding of space as multilayered, plural and provides the backdrop against which many types of image can be projected. It is decentered, dispersed and networked. In this framework, this article examines the postmodern space in the digital age. In contemporary culture, people live out latitude lives in digital world where they can stamp out their identity and lifestyles in whichever paths or forms they choose. In another words, virtual spaces spread out the alternatives in different fields of life, including politics, communication, beliefs, leisure, education and healthcare which have had penetrative alterations in many societies. The creation (man made) of virtual spaces has composed a new way understanding of the meaning of space.

Virtual space is a term of rising and expanding significance in today's world. As Kellerman (2016: 30) addresses that virtual space is "the visual presentations of real space and material artifacts in all forms". Virtual spaces within cyberspace may be possibly involved within virtual worlds, which are computer-composed simulated habitats, often letting for multiple users. The geography of online world contains "artificial" and unembodied information. The users interpret life online through switching from one internet window to another, experience the practice and exit as they will.

Virtual spaces have penetrated the physical spaces by touching and changing the perception of the user's experience of the environment. In its beginning cyberspace was useden as something that was out there, as an imaginary space that had a clear distinction from physical space but that was ensnared with it a chance. Moreover, virtual space enacts a 
blurring of boundaries, which extends geographical borders and challenges a users' persistence within the postmodern era. While many discussions regarding the virtual space have centered on the notion that an alteration to traditional structural forms has occurred postmodernity embeds the realization that forms or operates in a state of continual change.

This article establishes a framework for interrogating space through brief explorations of discursive meanings. The concept of space is extended to include not only physical but also virtual space as well. Virtual space is produced and reproduced. At last, this study argues that virtual space is postmodernist because it can be interpreted in an unlimited number of ways by an unlimited number of individuals. These individual interpretations are formed from a lived space, they are shaped by social and cultural factors that become trended in similar groups of people. It is in this way that affective readings can be created and triggered, interactive space is designed from the users' experience of the life and their understanding of how the choices of the people from this world can be affected.

Keywords: Postmodernism, Space, Virtual Space

\section{Giriş}

Postmodern düşüncenin, mekân algısı belirsizliklerle kendini gösterirken, detaylı mekân tasvirlerinin bulanıklaştığı gözlemlenir. Modern düşünce içinde mekân kendini simgesel değerler üzerinden gösterirken, postmodern düşünürlerce "hyper mekân" olarak adlandırılan mekân ise değişkenliklerin sıklıkla yer aldığı, belirginliklerin olmadığı bir yer olarak açıklanır. Lefebvre, gündelik yaşam aktivitelerini zaman ve mekân süreçleri çerçevesi içinde inceleyerek, mekânın, mekânsal bağlamının toplumsal değer ve anlam algısından üretildiğini belirtmiştir (Schmid, 2008: 25-46). Günümüz teknolojiye dayalı bilgi toplumu, mekânlara dijital yeni özellikler kazandırmakta, mobil iletişim teknolojileri ile de etkileşimin yüksek olduğu sınırsız mekânlar oluşmuştur.

Mekânların görsel kolaj biçiminde yer aldığı geleneksel medya yerini günümüzde gerçeklik ile temsili arasındaki ilişkinin belirsizleştiği yeni medyaya bırakmaktadır. Günümüzde, dijital dünyanın hızla toplumsal yaşama entegre olmasıyla, gündelik yaşamın her alanına nüfus eden yeni medya adı altında yeni mekânlar yaratmıştır. Yeni medya ortamında yer alan karmaşık bilgi aktarımı yapısı gündelik yaşam eylemlerinin fiziksel mekânlarını değiştirmiş, yeni dönüşümler yaratmıştır. Gösterge ve imaj tüketimine dayalı postmodern toplum kendine gibi sosyal medya gibi farklı sanal mekânlara ait yansımaların toplumlar tarafından tüketildiği ve yansımaların özgünden daha gerçek biçime girdiği küresel mekânlar yaratmıştır (Çubuklu, 2000: 63).

Toplumlar da değişen geleneksel mekân algısı, bu yapılandırmalarla birlikte yeni bir kültürel düzenin de oluşmasına sebep olmuştur. İletişimin küreselleşmesi, sosyal ilişkilerin de küreselleşmesini beraberinde getirerek siber mekânlar (sanal mekânlar) ortaya çıkmıştır. Sanal mekânlar, sanal gerçekliğin en önemli unsuru internet ile gündelik aktivitelerin ve deneyimlerin merkezine yerleşmişlerdir. Bu sanal mekânlar yeni etkileşim ve dönüşüm ortamı olarak yeni iletişim modellerini yapılandırmakta olup aynı zamanda da sanallığın içinde kullanılan terimlerle de bize "sanal dünyanın" adreslerini, pencerelerini gezinme (navigation) imkânı yaratmıştır.

Bu çalışmada öncelikle mekân, kavramsal ve kuramsal çerçevede ele alınarak, tarihsel gelişim çizgisi değerlendirilmiştir. Ardından postmodernizm kavramsal olarak incelenerek, mekânın tarihsel 
süreç içinde edindiği farklı anlam örüntülerinin günümüz postmodern dünyasında kazandığı yeni anlam ve algılar yeni medya çerçevesi içinde irdelenmiştir.

\section{Mekân Kavramı ve Etrafinda Oluşturulan Anlam Örgüsü}

Arapça bir kelime olan mekânın sözlük anlamı "var olanların içinde yer aldığı, tüm sınırlı büyüklükleri içine alan uçsuz bucaksız büyüklük; boşluk; sınırsız ortam; yer kaplama" dır (Cevizci, 1997: 468-9). Kevn sözcüğünden türeyen mekân aynı zamanda "varlık; oluş; sınırsızlık ve süreklilik; belli bir şekle girmek vb." anlamlarına da barındırmaktadır (Yıldız ve Alaeddinoğlu, 2007: 846). Mekân kavramı hakkında yapılan ilk çalışmalar, çoğunlukla kültür coğrafyacıları ve mimarlar tarafindan gerçekleştirilmiş olup, insan ve çevresi arasındaki ilişkinin sosyal bilimlerin birçok alanının ilgi alanına girmesiyle günümüzde multidisipliner bir hal almasıyla sonuçlanmıştır.

Tarihte kavrama ilişkin ilk anlam yükleyenlerden Aristotle, mekânı, tüm yön ve özellikleri içeren yerlerden (space) oluşan etkin bir "saha" olarak yorumlamıştır (Demirkaya, 1999: 4). Parmenides ise mekânı var olmayan bir şey, mutlak bir yokluk olarak irdeler. Descartes, mekânı maddeyle özdeşleştirerek asla boş bir mekânın olamayacağını çünkü mekânın içinde bulunan cisimlerden ayrılmadığını savunmuştur. Leibniz ise mekânların mantıksal birer ürün olarak sadece toplumsal ilişkiler sonucu oluşan bir durum olduğunun altını çizerken (Cevizci, 1997: 468-9), Kant ise mekânı, maddeden farklı ve ondan bağımsız olarak vurgulamıştır (Demirkaya, 1999: 5).

Jameson, gündelik yaşamımızda yer alan kültürü belirleyenin mekânsal kategoriler olduğunu belirterek mekânın yalnızca coğrafyanın temel konusu olmadığını aynı zamanda sosyal bilimlerin de çalışmalarına girdiğini vurgular. Bu çerçeve içinde Braudel ise sosyal bilimlerin tüm dallarının insanı nasıl mekân içerisinde kavramsallaştırma çalışmalarına ağırlık vermeleri gerektiğini belirtir (Akt.: Işık, 1994: 8-9). Giddens (2005: 384), tüm toplum ilişkilerinin zaman-mekân düzleminde ortaya çıktığını ve mekânsal yansımalar olmadan zamanı incelemenin mümkün olmadığını belirtir. Bunun gibi, coğrafya anlayışındaki mekân, günümüzde ise iktidar mekânları, eğlence mekânları, eğitim mekânları, direniş mekânları, kişisel gelişim mekânları, korku mekânları, teknoloji mekânları, sanal mekânlar, vb. gibi anlamları edinerek farklı alanların içine nüfus etmiştir (Yıldız ve Alaeddinoğlu, 2007: 848).

İnsan ile mekân arasında var olan etkileşimli ilişki, mekânın sadece ontolojik bir anlamı olmadığını aynı zamanda da insanın yaşamında çok etkin bir boyut olduğunu savunan Harvey (2003: 11-34), mekânsal biçimlerin toplumsal süreçler içinde şekil aldığını belirtmiştir. Soja (1996) ise Lefebvre'nin "temsilin mekânlarından" esinlenerek Üçüncü Mekân kavramlaştırması yapar. Her şeyin bir araya geldiği, öznel-nesnel, soyut-somut, gerçek-hayal, ayrımlarının olmadığı bu Üçüncü Mekân'da farklı bir araya gelişlerin (kişi, aktör ve bağlamın) kurgulandığı "melezlik" meselesinin altı çizilir.

Sosyal bir inşa olan mekânlar, toplumların belirli kalıplar içinde düşünmelerini ve yaşamalarını sağlarken şimdiyi kurmada ve geleceği planlamada önemli bir araç konumundadır. Birbirlerini sürekli ve dinamik bir şekilde biçimlendiren toplum ve mekan ilişkisi bir sosyal ilişki tarafindan yapılandırılmakta olup aynı zamanda da sınıflar, bölgeler, adetler gibi güç meselelerinin de eylemleştiği süreçlerdir (Shields, 1991: 57). Urry (1999: 97), resmin tamamını görmek için mekanın sosyal inşa ediciliği çerçevesinden bakılması gerektiğini belirterek yalın mekanların olmadığını, sadece mekânsal ilişkilerin ve mekânsallaşmaların var olduğunu savunmuştur. Mekân somut hale büründükçe ve kazandığı anlamlarla zenginleştikçe simgesel ve mecazi kazanımlar elde eder hâle gelir (Schick, 2001: 7).

Urry (2015), "taking place" (yer almak ve/veya gerçekleşmek) deyişi ile eylemin mekânda gerçekleştiğine işaret ederek mekânsal var oluşa dikkat çeker. Mekân sosyolojisinde Urry (2015), öncelikle mekânsal olanın toplumsal olandan ayrılamaz olduğunu belirterek mekânın, tek başına kurgulanamadığını ve anlam bulamadığını vurgular. Üç farklı mekânsallaşmanın mevcut olduğunu savunan Urry, bunları şu şekilde açıklar: Birincisi, günlük yaşamın rutinleri zaman- mekân içinde 
dağıtılırlar. İkincisi, toplumsal kendilik nesneleri (üretim ilişkileri, devlet, sivil toplum, sınıflar vb.) ancak zamansal ve mekânsal bağlantılar sayesinde gelişir.. Üçüncüsü ise bu toplumsal kendilikler, zaman ve mekân anlatıları ile dinamik bir ilişki içindedir (Urry, 2015: 98-100).

Türkçede mekân kavramı ve yer kavramı kulanım bakımından bir ayrıma sahip olmasa da gerek kapsam ve gerekse içerik açısından farklıdır. Hayden (1997), yer kavramı için ev tınısına sahip bir konum olarak betimlerken kentin kamuya ait açık alanları gibi anlamları da taşığını belirtirken toplumsal hiyerarşide yer alan bir pozisyon anlamına da geldiğini vurgular. Mimarlık, kültürel çalışmalar, fotoğraf, film, şiir, gezi kitaplarının yazarları, estetikliğe biçim vermek için "yer" kavramını bir duygu akışında kullanırken, açıklamanın bir alternatifi olarak "yerin kişiliğì" isimlendirmesini tercih ederler. Öznelliğin ve deneyimin vurgulandığı bir anlayışa sahip yer, Cresswell'e (2004) göre mekâna göre daha somut bir kavramdır. Augé de (1995), "yer" kavramının post modernliğin etkileriyle tekrar ele alınmasını savunmuş, "yer olmayan" mekânların bu dönemde üretildiğini iddia etmiştir. Değişim geçiren yer, "yer-olmayanlara" dönüşmüş, ruhu olmayan, anlamdan, deneyimden, pratikten bir anlamda yoksun geçiş noktaları (süpermarketler, fast-food alanları hava alanları, tatil köyleri, vb.) olmuştur.

De Certeau (1984) ise, mekânın eylemler tarafından üretildiğini, yer için de, üzerinde eylemlerin meydana geldiği boş bir sistem olarak görür. Başka bir deyişle mekân pratik edilen yer olup, belli bir varlığın hem tek yönlülüğünü hem de durağan olma durumudur. Harvey (1991: 294), yeri (place) iki tanımla açıklar. Birincisi, "yer" bazı sosyal süreçler sonucu oluşturulmuş zaman ve mekân haritasında bir durum ya da konumdur. İkinci tanımda ise "yer", zaman ve mekân düzleminde oluşan bir 'süreklilik' ya da 'oluş'tur. Tuan'da (2003: 3), insan ve yer arasında bir duygusal bağ olduğunu savunarak, özgürlüğün yansıması olan mekânın geleceğe vurgu yaptığını ve bunun sonucunda da hep dinamik ve hareketlilikle eşleşeceğini, ancak "yer"in hep bir dinginlik içerdiğini belirtmiştir. Yer kavramı yerine lokal terimini yeğleyen Giddens (1999: 171-2), mekânın bir etkileşim alanı yaratmasından ötürü yerden ayrıştığını savunur. Shields (1991: 42) ise "yer" için mekânların alt gruplarına ait olduğunu savunmuştur. Toplum-mekân sarmalı içinde mekân, öznesi tarafından deneyimlenirken bireysel ve sosyolojik kendilik nesnelerin, toplumsal yapıların, kültürel yorumların, politikaların ve ideolojik çözümlemelerin yansıdığı bir sürecin çıktısı olmuştur. Kısaca, “yer”leri ve mekânları zıt kavramlar olarak düşünmek yerine insanın algılamalarını ve deneyimlerini aktaran konumlar olarak yorumlamak gerekir.

\section{Postmodernizm ve Postmodern Dünya}

Postmodernizmin tanımında bir kesinlik mevcut değildir. Her yazar postmodernizmi, kendi bakış açısından yorumlayarak bir kılıfa sokmaya çalışır. Kimine göre postmodernizm modernizmden bir kopuş kimine göre ise modernizmin bir üst seviyesidir. Bazı araştırmacılar da postmodernizmi bir kolaj tekniği olarak betimlerken bazıları da tarihin sonunu ilan eden bir akım olarak ifade etmektedir (Fukuyama, 1993, 13-52). Günümüz dünyasının bir postmodern çağ olduğu ileri sürülürken aynı zamanda bu süreçte aklın sınırları genişlemiş, ideolojiler tükenmiş, mekân ve zaman anlayışımızın boyut değiştirmiş olduğu ifade edilir. Lyotard (1991: 8-9) “ üstanlatıların ${ }^{1}$ sonu” diye tanımladığ1 postmodernizmi, bilimde ve bilgide geçerli olan tek bir üstanlatının değiştiğini ve dönüştüğünü savunur.

Postmodernizm hakkında yapılan araştırmalar 1980’li yıllarda ivme kazanmış, içeriği kavramsal boyutlarda incelenmiştir. İçerik olarak bazı araştırmacılar postmodernizmi yeni teknolojiler çağı olarak yorumlamış, küreselleşme kavramıyla birlikte "enformasyon devriminin" bir algısı olduğunu belirtmiştir. Gündelik yaşamdaki değişiklikler, teknolojik devinimlerle birlikte şekil değiştirmiş, geleneksel medyanın alternatifi yeni medyanın toplumsal süreçleri değişime uğratmıştır. Bazı

\footnotetext{
${ }^{1}$ Üstanlatı farklı anlatıları tek bir kural içinde, çokluğu tek bir anlatıya indirmedir Lyotard'a göre modernizm bilgiyi organize eden bir üstanlatı türüdür (Readings, 1991: 48).
} 
araştırmacılar ise postmodernizmi çoğullaşma ve parçalanma olarak betimlemiş başlama ve bitişin olmadığ 1 süreçler olarak ifade etmişlerdir (Soykan, 1993, 117).

Baudrillard'a göre postmodernizm, sibernetik (güdüm bilim) tarafindan yönetilen bir enformasyon ve göstergeler çağıdır. Ona göre postmodern dünyada imaj, simülasyon ve gerçeklik arasındaki sınırlar ortadan kalkmış, kitlelerin sürekli mesajlarla çevrelendiği durumlar oluşmuş ve bunun sonucunda da postmodern dünya anlamdan yoksun bir hale gelmiştir (Aktaran, Best ve Kellner, 2011). Bu çerçevede postmodernizm için gerçek bilimin somutlaştırdığı akıldan ve temel gerçeklikten kuşku duyan bir düşünce tarzı olduğu söylenebilir.

Postmodernizm nasıl tanımlanırsa tanımlansın temel yapısını modernizm içinde bulan "yeni" bir felsefi bakış, sosyolojik düşünce, biçim ve yeni bir söylemedir. Sınırları var olan bir tanımın içine sığmayan postmodernizm kullanıldığı farklı alanlara bağlı olarak yeni ve değişik anlamlar edinebilir. Felsefe alanında kendisinden önceki epistemoloji, ontoloji ve etik yaklaşımları sorgulaması onu betimlerken aynı zamanda eklektik bir tavırla yeni ve farklı olanı da yansıttığı söylenebilir. Kimi zaman karşı duruşların içinde yer alırken kimi zamanda geleneksel tartışmaların merkezinde kendine yer bulur (West, 1998: 261).

Tek bir dünya içindeki çeşitlilik, ileri teknolojiler ve iletişim alanındaki gelişmelerle birlikte yeniliklerin ve bilginin hızlı aktarımına yol açmışır. Günümüz toplumları da meydana gelen bu değişimlere ve gelişmelere, interneti yaygın bir biçimde kullanarak bilgi alışverişini siyasi, ekonomik ve kültürel düşünce bazında yaymaktadır. Büyük ölçekli üretime dayalı sosyal ve ekonomik organizasyonlar yerini postmodern dönemde bilim ve teknolojiye bırakmış ve bilgi bir sistem içinde toplanmaya başlamıştır. Postmodern dünya anlayışı da bu çerçevede bilginin keşfinin, icadının, imâlinin ve üretiminin giderek daha çok önem kazanması biçiminde şekillenmesi olmuştur. Bu karşılıklı etkileşim süreci de toplumda yeni mekânların oluşmasına sebep olmakta, toplumun geleneksel mekân algısı değişmektedir.

\section{Postmodern Mekânlar}

Modern dönemde, mekân konusundaki çalışmalar kesinlikler ve sınırların çizilmesi üzerinedir. Modern mekân algısı, tanımlanabilir özellikler içinde gerçekliklerin mekândan ayrı tutulmadığı ve sıkı bağların kurulması biçimindedir. Lefevbre, mekân algısında parçalanmanın 1910'larda başladığını belirtir ve o döneme kadar mekân, belirli sınırlara ve anlamlara sahipken, daha sonra, bu mekân anlayışının değiştiğini ve farklı alanlarda bu değişimin etkilerinin görüldüğünü belirtir (Lefevbre, 1991: 25). Postmodernist düşünürler ise bu mekânsal algı değişiminin Jameson'ın "Așırı-uzam”’ olarak adlandırdığı anlama biçiminin sonucunda oluştuğunu savunurlar. Bunun sonucunda öznelerin kendi yerlerini bulmaları da zorlaşmıştır.

Postmodern mekânın derinsizliğinde, özne kendi benliğini kaybeder. Mekân kendi konumunu belirleyemez ve onunla etkileşimli ilişki kuran öznenin kendi konumunu bulması zordur. Modern mekân somut bir uzamken, postmodern dönemde soyutlaşır. Postmodern dünyada sınır ve kurallar yoktur ve bu durum mekân çalışmlarında da gözlemlenir (Uçan, 2009: 2291). Postmodern dönemde mekân artık, bambaşka bir boyut kazanmış, tasvirler kısalmış "hyper mekânlar" oluşmuştur. Mekânsal engellerin ortadan kalktığı (Cevizci, 213: 782) süreçler sayesinde örneğin bazı bilgisayar markalarının, dünyanın çeşitli bölgelerinde üretilen parçalarının ABD'de birleştirilmesi firsatları oluşmuştur.

Kolaj mekân algısı, "küresel köy" yapısının teknolojik gelişmelerin bir sonucu olarak oluşmuş, yan yana gelmesi düşünülemeyen mekânların yan yana duruşlarının olduğu durumlar meydana gelmiştir. Örneğin, Paris'e ait mekânsal bir özelliğin ya da ABD'nin modern mekân ayrışımlarının İstanbul'da bir kafede yer alması iki mekânı yan yana getirmiştir. İnsanlar, internetle birlikte kendi

\footnotetext{
${ }^{2}$ Mekân anlayışı bu çerçevede içerisi-dışarısı kategorilerinin etkisini yitirdiği ve mekânsal konumlandırmanın ortadan kaybolması olarak değişir (Jameson, 2011: 156).
} 
coğrafyalarının dışında dünyada gerçekleşen olayları hatta savaşları, aynı anda izlemektedirler (Sim, 2006: 51). Virilio (1989: 112), siber-uzamla insanların, somut mekân içinde dolaşmaya ihtiyaç duymadığını belirterek bu esnek mekân ile maddenin sınırlarını zorlarlar. Bu sebeple, siber mekânlar icat edilebilir velya da kolaylıkla silinebilinir.

Postmodern mekânlar, bilinen mekân algısını tümüyle değiştirir ve İnternet ile de fiziksel olarak mekânlarda bulunulmasına gerek kalmaz. Harvey (1969) postmodern kültürün mekânın dönüştürülmesinde önemli bir rol oynadığını belirtir, nitekim Çantada ya da ceplerde taşınan bilgisayarlar ve akıllı telefonlarla Postmodern özneler, bulundukları yerden dünyanın diğer bir ucunu kolaylıkla sanal olarak gezebilirler. Bu çerçevede içerisi ve dışarısı kategorileri önem yitirmekte, neyin iç neyin diş olduğu belirsizleşmektedir.

Günümüz popüler kültürü postmodern mekânla var olmaya, görünür kılınmaya, temsil edilmeye devam eden bir yapıdadır. Harvey'in (1969) "zaman-mekân sıkışması" kavramı, her coğrafyanın kendine özgü bir hikâyesi olduğu, her bir mekânda deneyimlenecek bir şeylerin olduğu, postmodern mekân çalışmalarına ayrı bir bakış açısı sağlamıştır. Bu bakış açısı, hem postmodern düşünürlerin betimlediği kültürel göreceliliği savunurken hem de postkolonyal eleştirilerin ifade ettiğ "öteki" coğrafyaların bakışından kültür algılamasının ya da deneyimlemesinin sonucu ortaya çıkan bilgi inşaasının yaratılmasını da sağlamıştır. Bu nedenle, mekânların özgünlügünü esas alan kültür çalışmaları çoklu ve sınırları olmayan bir mekân algısı oluşturmuştur.

2008 yılı Nobel ödülünün, ekonominin mekânsal ve kültürel bağlamını öne çıkaran Krugman’a verilmesi, 1990'larda küreselleşmeyle birbirinden değişik olan yerelliklerin ya da mekânsallıkların çalışılmaya başlanmasının bir çıktısıdır. Sanayi, (Asheim, 1996; Amin and Thrift, 1992) değişen mekânsal boyutlarla yeni kavramlar edinmiş, günümüz ekonomik faaliyetlerinin yalnızca fiziksel mesafenin yarattı̆̆ taşıma ve ulaştırma maliyetleri ya da mekânsal işgücü bölümlenmesi olarak sorgulanmamaya başlamıştır. Yeni postmodern dünyada ekonomik yapı çoklu ölçeklerle başka coğrafyalarla bağlantılar kurmuştur. Sosyal ve ideolojik üretim alanı olarak mekân, bağımsız ve edilgen durumuyla çok boyutlu ilişkilerin oluşturulduğu soyut biçime kavuşmuştur (Soja, 1989). Postmodernizm süreci sonunda mekân algısında ortaya çıkan bu değişim bugünün toplumsal gerçekliğinde yer alan karmaşa ve parçalanmışılı̆ıda yansıtmaktadır. Çoklu perspektiflerle mekân postmodern dünyada kısaca işlenerek sınırlardan kurtarılmıştır.

\section{Postmodern Mekân ve Sanal Mekân}

Modern dönem öncesi toplumlarda mekân ve yer aynı anlamlarda kullanılırken, belirli sınırlar içindeki toplumsal ilişkilere işaret etmekteydi. Toplumsal yaşamın etkinlikleriyle belirlenen mekân fiziksel eylemlerin meydana geldiği tasvirlerle organik bir biçime sahipti. Modern dönemlerde ise zamanın bölünebilir ve evrensel ölçülebilir şekil kazanması mekânın da yeni anlamlar kazanmasına sebep olmuştur. Giddens'a (1998) göre modernlikle birlikte, kapitalist ekonominin dünya geneline yayılması sonucu mekân yüz yüze ilişkilerin etkinliğinden ayrılarak artık sadece somut bir kavram kılıfından çıkmıştır. Aynı zamanda da toplumsal etkinliklerin vuku bulduğu fiziksel özelliklerinden de sıyrılan mekân, böylece her yerde ve her zaman istenildiği şekilde düzenlenebilir ve bölümlenebilir kavram olmuştur.

"Yaratılmış mekânların” 2000'lerle hız kazanmasını kapitalist ilişkilerin bir çıktısı olarak gören Urry (2015: 48), mekânın, yerin ve bölgenin küreselleşme süreçlerinin sonucunda yeni biçiml ve anlamlar edindiğini belirtir. Bu süreçle birlikte mekân algısı değişmiş, bir dönüşüm içine girmiş, tüketimin de alanı olarak, bir tür 'mekân tüketimi'ni içermiştir. Sanayileşmeyle birlikte mekân daha önce tarımsal ilişkiler sonucu şekillenme anlamını yitirmeye başlamış, iş dünyası için üretim sürecinin bir parçası haline gelmiştir. Bu yapılanmanın sonunda, tüketim merkezli kentlerde mekân olgusu çağımızın postmodern dünyasında parçalanmışlık ve bölünmüşlükle yeni bir perspektif kazanmıştır. Postmodern yapılandırma sonucu metalaşan mekânı Urry (2015: 187) modernleşme sonunda soyutlaşan, 
mantık sınırlarını zorlayan, homojen ve mimarinin temeli olarak görürken; postmodernist düşünce ile lokal çalışmalara ağırlık veren ve değişik biçimlere giren kökenlerini geleneklerde yaratan, kimseye benzemeyen,hem belirsiz hem de bir bağlama bağl1 olarak görür.

Modern kentlerde tüketim amaçlı yeni mekânların oluşumu (AVM'ler, süpermarketler, vb.) ve iş dışı zaman geçirilen mekânlar (cafeler, barlar, lookantalar, vb.) modern kentte 'mekânın tüketimi' hızlandırmıştır. Baumann (2006: 25), işlenmiş ve örgütlenmiş mekân artık teknik kapasite ve teknik eylem hızı ile oluşmaktadır. Görsel tüketim malzemelerinin kolaj biçiminde TV ekranlarında anlık geçişi, geleneksel zaman yapısını yok ederek mekana ait algının değişmesine yol açtığını beliritir. Bununla birlikte gerçeklik ve temsilin arasında var olana ilişki gün geçtikçe bulanıklaşmakta olup postmodern toplumlar gösterge ve imaj tüketimi üzerine şekil almaktadır. Temsilin orjinalden daha gerçek olduğu bu dönemlerde, kurgulanmış yeni mekânlar TV ekranlarına, sonra da dijital ortama taşınmaya başlamıştır.

Önce televizyonun toplumsal yaşama entegrasyonu yeni bir kamusal yaşam biçimi yaratılmış ve diş deneyim ile iç deneyimin ilişkisi Castells'in belirttiği gibi "görüntü mekânları" sonucunda birbirinden kopmaya başlamıştır (Akt. Morley ve Robins, 1997: 56). Günümüzde, önceleri uydu ve kablolu yayınlar aracılı̆̆ıyla başlayan şimdilerde de dijital yayınlarla birlikte artık bu "görüntü mekânları" dünyanın en uzak köşelerine ulaşabilmektedir. Toplumlarda yer alan geleneksel mekân algısının yitirilmesine sebep olan bu çoğul eylem, yeni bir dijital kültür yapının da oluşmasına neden olmaktadır. İletişimin küresel boyutlara ulaşması, sosyal ilişkilerin de küreselleşmesini sağlayarak siber mekânların (sanal mekânlar) ortaya çıkmasını sağlamıştır.

Sanal, gerçeğin katmanlarından biri olup gerçeğin karşıtı değildir. Sanal kavramı, gerçek olanı tanımlarken somut olmayanı da tanımlar (Franck, 2000). Sanal gerçeğin değil, sahicinin zıddıdır (Kayapa, 2003). Baudrillard ise sanal ortamları "simülasyon" olarak betimlerken, medyayı daha çok da televizyonu sanal ortam olarak yorumlar. Bu noktada gerçeklilten koparılmış kültürel nesneler temsil yoluyla kelimelerin ve imgelerin içine sıkışmıştır (Uluoğlu, 2000). Mekânlar arası hiyerarşi, kullanıcının nereye hangi pencereden gireceği belli olmadığından silikleşmiştir. Ayrıca, mekânsal görünümlerde her an değişebildiğinden önemini yitirmiştir (Boyer,1996).

Sanal mekân, tanımı olmayan, sınırsız, esnek ve sürekli değişkendir ve geleneksel mekândan özerk bir zemini vardır. Fiziksel kuralların yer almadığı siberuzayda, gerçek dünyanın bir izdüşümü olarak yeniden yaratılır ve yaratılan bu dünyada yeni gerçeklik düzeni vardır. Siberuzay sınırları olmayan alanıyla kullanıcılarına istemedikleri kadar özgürlük sunmaktadır. Fiziksel dünyadan öykünen sanal mekânlar maddesiz maddelerden oluştuğu için sınırları, dokuları, renkleri, yüklenen sınırsız göstergelerle sürekli değişir, deneysel alan sağlar. Siberuzayda inşa edilmiş bir mekân, fiziksel biçimlenmeye ve statik olmaya ihtiyaç duymaz. Bunun sonucunda da sınırları olmayan bir mekân kavramının kapıları açılır.

Günümüzün metropollerinde sosyal işlevleri bulunan merkezler ortadan kalkmış, yerini sanal mekânlar üstlenmiştir. Ticaretten, çalışmaya, eğlenceden eğitime olan tüm yaşamsal etkinlikler gerçek mekân yerine sanal mekânlara taşınmışlardır. Sanal mekânlar, internetle birlikte televizyonlardan bilgisayar oyunlarına, sosyal medyadan arama motorlarına kadar günlük yaşamın merkezinde yer almaktadır. Bu mekânlar aracılığıyla yeni etkileşimli iletişim ve dönüşüm ortaya çıkmış, toplum-mekân ilişkisi yeni bir boyut kazanmıştır. Gerçekliğin olmadığı dünyaların yaratıldığı bu sanal mekânlarda, bireyler fiziksel bir temas içinde olmadan sanal gerçekliğin içinde ilişki kurmakta, Robins'in (1999: 164) ifadesiyle toplumsal karşılaşmaların yer almadığı biçimler oluşmaktadır. Bu sentetik mekânlarda zaman donmuş, yerleşik toplumlar oluşmamıştır.

Bireyler, sanal mekânlarda "seyahat", "boş zaman" ve "mesafe" kavramlarına yeni anlamlar yüklemeyerek, geleneksel toplum ve mekânsal bütünlüğün parçalara bölünmesine yol açmıştır. Mekânlar-arası yolculuk, artık uzaklaşma hissi vermemekte tam tersine yakınlaşma hissini 
yaratmaktadır. Coğrafi mekân değiştirmeye alternatif olan sanal mekân değişimi akışkan kimliğe sahip turistlere hızlı bir tüketim imkânı tanımıştır. Paylaşılan mekân görselleri mekânlar arasındaki farklılıkları azaltmış, metalaşmış bir yolculuk anlayışı doğmuştur. Dijital mekanlar yeni bir gerçeküstücülük imkanı ile bireylere mekânsal göstergeleri bir simülasyon biçiminde sunmaya başlamıştır.

Postmodern dünyada mekânsal ve toplumsal yapıların değişimi ile birlikte sanal gerçeklik denen kavram elektronik bir coğrafyanın yaratılmasına katkıda bulunmuştur (Morley ve Robins, 1997: 155). Küresel köye evrimleşen günümüz dünyası, sanal mekânlar yaratmaya devam ederken, mekânların hem yapısal hem de anlamsal olarak değişime uğramasına neden olmuştur.

\section{Sonuç}

Bu çalışmada son çeyrek yüzyılda postmodern bakış açısıyla birlikte değişen mekânsal anlayış açıklanmaya çalışılmıştır. Bu amaçla, ilk olarak mekân kavramının anlam örüntüsü "yapı" ve "tasarım" çerçevesinde incelenmiştir. Yeni mekân anlayışının yol haritası sanal mekân kavramı üzerinden izlendiğinde, çalışma daha sonra postmodern dünyadaki sanal mekân kavramının üzerinde durmuştur. Çalışmanın temel vurgusu, yeni mekân anlayışı içinde sanal mekânların postmodern dünyada nasıl algilandığıdır.

Mekânı sadece betimleyici bir form olarak değil, yeni bir anlayış biçimi olarak incelemeli ve sosyal durum perspektifinden yorumlamalıdır. Postmodern dünyanın içinde yer alan sanal mekanları da bu perspektifle toplumsal bir metin olarak kabul etmeli ve epistemolojik çoğulculuğa sahip bir balış açısından irdelenemelidir. Postmodern bilincin üzerine inşa edilen sanal mekânlar, dönüşüm ve değişimin devamlı altını çizerek "postmodern coğrafyaların" çıktısı olan mekânsallığa vurgu yapan algılar yaratmaktadır. Bu anlamda günümüz toplumsal gerçekliği fiziksel dünyanın yansıması olan ama kararsız bir mekânsal boyutta yer almaktadır. Böylesine belirsiz ve parçalanmış postmodern mekân algısı olasılıkların ve alternatiflerin olduğu bir etkileşimi de beraberinde getirmektedir.

Sürekli gelişim durumunda olan sanal mekânların teknik dille "yapım aşamaları" hep devam etmektedir. Bireyler kullanıcı rolleri ile gerek sosyal medya aracılığıyla zaman ve mekân çerçevesinde diğer kullanıcılarla etkileşmekte gerek dijital medya ortamında dolaylı ve görsel algılama üzerinden iletişim kurmaktadır. Baudrillard (2003), orjinal ve kopyası ile gerçek ve sahtesi arasındaki farkın bulanıklaşmasını gerçekliğin yok oluşu olarak vurgular. Simülasyon, etkin olduğu post modern dönemin tüm belirsizlikleriyle kendini sanal mekânlarda da gösterir. Hyper mekân deneyimi bireyler tarafından daha gerçek olarak algılanmakta, fiziksel mekânın sınırlılıklarını aşarak başka bireylerle sanal olarak bir araya gelmelerini sağlamaktadır (Tansel İliç, 2015: 127).

Değişen toplumsal koşullarla birlikte yeni anlamlar alarak şekillenen mekân gerek sanal boyutuyla insanların değerlerini, gerek kültürlerini ve yaşam biçimlerine etki etmeye devam etmektedir. Küreselleşme ile birlikte yaşam alanları genişlemekte, yaratılan hyper mekânlarla da mekân algısı sınırlarından kurtulmaktadır. Bu çerçevede mekânsal okumalar günümüz postmodern toplumlarında tek bir düzlem üzerinden yapılamamaktadır. Çoklu postmodern coğrafyalar yeni bir mekânsal okuma biçimi geliştirmekte, "yeni görme ve anlama biçimlerine açılan kapılar" geliştirmektedir (Burnett 2007: 81).

\section{KAYNAKÇA}

Asheim, B.T. (1996). "Industrial districts as 'learning regions': A condition for prosperity", European Planning Studies, Volume 4(4), 379 - 400.

Amin, A. ve Thrift, N. (1994). Globalization, Institutions, and Regional Development in Europe. Oxford University Pres: Newyork. 
Augé, M. (1995). Non-Places: Introduction to an Anthropology of Supermodernity. Verso: New York, Ayman, Z. (2006). "Bellek Mekânı Olarak Sınır ve Ötekilik: Kars Şehri”, Toplum ve Bilim, 107, 145189.

Baudrillard, J. (2003). Simülakrlar ve Simülasyon. (Çev. Oğuz Adanır). İstanbul: Doğu-Batı Yayınları

Best, S. ve Kellner, D. (2011). Postmodern Teori. (Çev: M. Küçük). İstanbul: Ayrıntı Yayınları.

Boyer, M.C. (1996). Cybercities. Princeton Architectural Press, New York

Cevizci, A. (1997). Felsefe Sözlüğ̈̈. İstanbul: Ekin Yayınları.

Crang, P. (1997). "Introduction:cultural turns and the (re)constitution of economic geography", Geographies of Economies, (Ed.) J.Wills ve R. Lee, 3 -15, Arnold: London.

Cresswell, T. (2004). Place: A Short Introduction. Blackwell Pub.: USA.

Çubuklu, Y. (2000). "Mekânların Ölümü”, Varlık, 1113, 63-64.

Demirkaya, H. (1999). Mekân Kavramının Tarihsel Süreç Iç̧inde Incelenmesi ve Günümüzde Mekân Anlayışı (Yıldız Teknik Üniv. Fen Bil. Enst. Yüksek Lisans Tezi), İstanbul.

Ecevit, Y. (2013). Kurmaca Bir Dünyadan. İletişim Yayınları: İstanbul.

Franck, O.A. (2000). Düşünce İçin Mimarlık - Sanallığn Gerçekliği, Mimarlık ve Sanal Gerçeklik Dosyası, Arredamento Mimarlık, Kasım Sayısı, Boyut Yayıncılık, İstanbul.

Fukuyama, F. (1993).Tarihin Sonu Mu?. Çev: Yusuf KAPLAN, Rey Yayınları: Kayseri.

Giddens, A. (1999). Toplumun Kuruluşu. (Çeviren: H. Özel). Bilim ve Sanat: İstanbul.

Giddens, A. (2005). Sosyal Teorinin Temel Problemleri . (Çeviren: Ü. Tatlıcan), Paradigma: İstanbul.

Harvey, D. (2003). Sosyal Adalet ve Şehir. (Çeviren: M. Moralı), Metis Yayınları: İstanbul.

Harvey, D. (1969) Explanation in Geography. Hodder Arnold Publication.

Hayden, D. (1995). The Power of Place: Urban Landscapes as Public History. Mit Press: Cambridge.

Işık, O. (1994). "Değişen Toplum/Mekân Kavrayışları: Mekânın Politikleşmesi, Politikanın Mekânsallașması", Toplum ve Bilim, Sayı 64-65, Kıș

Jameson, F. (1994). Postmodernizm ya da Geç Kapitalizmin Kültürel Mantı̆̆ı. (Çev. Nuri Plümer), Yap1 Kredi Yayınları: İstanbul.

Kayapa N. (2003). Sanal, Sanal Kültür ve Mimarlık, Yükseklisans Tezi, İ.T.Ü Fen Bilimleri Enstitüsü, İstanbul.

Kellerman, A. (2016). Geographic Interpretations of the Internet. Springer: Dordrect

Lefebre, H. (1991). The Production of Space. Blackwell: Oxford.

Lyotard, J. F. (1991). The Inhuman: Reflections on Time. Polity Press: Cambridge.

Morley, D. Ve Robins, K. (1997). Kimlik Mekânları. (Çeviren: E. Zeybekoğlu), İstanbul: Ayrıntı Yayınları.

Readings, B. (1991). Introducing Lyotard Art and Politics. Routledge: London.

Robins; K. (1999). Imaj. (Çeviren: N. Türkoğlu), İstanbul: Ayrıntı Yayınları.

Schick, I. C. (2001). Batı’nın Cinsel Kıyısı: Başkalıkçı Söylemde Cinsellik ve Mekânsallık. (Çev: S. Kılıç- G. Sarı). İstanbul: Tarih Vakfı Yurt Yayınları. 
Schmid, C., (2008). "Henri Lefebvre's theory of the production of space: towards a threedimensional dialectic", K. Goonewardena et al., Space, difference, everyday life: reading Henry Lefebvre (p. 27-45). New York: Routledge

Scott, A.J., (2006). "A perspective of economic geography", Economic Geography: Past, present and future, (Ed.) S. Bagchi-Sen ve H.L. Smith, Routledge Studies in Economic Geography, 56-79.

Shields, R., (1991). Places on The Magrin: Alternative Geographies of Modernity. London: Routledge.

Sim, S., (2006). Postmodern Düşüncenin Eleştirel Sözlü̆̆̈̈. (Çev: M. Erkan, A. Utku). Ankara: Babil Yayınları.

Soja, E., (1996). Thirdspace. Malden: Blackwell.

Soykan, Ö. N., (1993).Türkiye'den Felsefe Manzaraları.Yap1-Kredi Yayınları: İstanbul.

Tansel, İliç, D. (2015). Sosyal Reyting: Biri Ne İzlediğimizi İzliyor. Sedat Özel (Ed.), Yeni Medya Çağında Televizyon, s. 109-128. İstanbul: Derin

Tuan, Y., (2003). Space and Place. Minneapolis: University of Minnesota Press.

Uçan, H., (2009). "Modernizm/Postmodernizm ve J. Derrida'nın Yapısökümcü Okuma ve Anlamlandırma Önerisi”, Turkish Studies - International Periodical for the Languages, Literature and History of Turkish or Turkic, Volume 4/8 Fall 2009, p. 937-950.

Uluoğlu, B., 2000. -miş Gibi, Mimarlık ve Sanal Gerçeklik Dosyası, Arredamento Mimarlık, Kasım Sayıs1, Boyut Yayınc1lık, İstanbul.

Urry, J., (2015). Mekânları Tüketmek. (Çev. R. G. Öğdül). Ayrıntı Yayınları: İstanbul.

Virilio, P., (1989). "The Least Vehicle", Looking Back on the End of the World. Ed. D. Kamper ve C. Wulf. New York: Semiotext(e).

West, D., (1998). Kıta Avrupası Felsefesine Giriş. (Çev. Ahmet Cevizci). İstanbul: Paradigma Yayınları.

Yıldız, M. Z. ve Alaeddinoğlu, F. "Küreselleşme Çağında Değişen Mekân Algılayışları”, İcanas 38, 845-862. 